\title{
Inspired or Foolhardy: Sensemaking, Confidence and Entrepreneurs' Decision-Making
}

\author{
James Cunningham $^{1}{ }_{(D} \cdot$ Alistair R. Anderson $^{1}$
}

Published online: 22 February 2018

(C) The Author(s) 2018. This article is an open access publication

\begin{abstract}
The purpose of this paper is to investigate the role of confidence in how both new and experienced entrepreneurs interpret and make sense of their business environment to inform decision-making. We illustrate our conceptual arguments with descriptive results from a large-scale $(n=6289)$ survey on entrepreneurs' perception of business performance and their decisions taken at a time of uncertainty in an economic downturn. Quantitative findings are stratified along experiential lines to explore heterogeneity in entrepreneurial decision-making and directly inform our conceptual arguments, while qualitative data from open questions are used to explain the role of confidence. Newer entrepreneurs are found to be more optimistic in the face of environmental risk, which impacts on their decision-making and innovative capabilities. However, the more experienced entrepreneurs warily maintain margin and restructure to adapt to environmental changes. Instead of looking directly at the confidence of individuals, we show how confidence impacts sensemaking, and ultimately, decision-making. These insights inform research on the behaviour of novice and experienced entrepreneurs in relation to innovative business activities. Specifically, blanket assumptions on the role of confidence may be misplaced as its impact changes with experience to alter how entrepreneurs make sense of their environment.
\end{abstract}

Keywords Confidence $\cdot$ Entrepreneurs $\cdot$ Decision-making $\cdot$ Experience $\cdot$ Mixedmethod

James Cunningham

j.e.a.cunningham@rgu.ac.uk

Alistair R. Anderson

a.r.anderson@rgu.ac.uk

1 Aberdeen Business School, Robert Gordon University, Garthdee Road, Aberdeen AB10 7QE, UK 


\section{Introduction}

Newly-formed businesses face many challenges and decisions in their efforts to succeed. While all small firms face uncertainty (Gheondea-Eladi 2016), newer businesses encounter greater difficulties than their established counterparts. Limited resources couple with the liabilities of newness and smallness; weaker ties with suppliers and customers and lack of experience all contribute to the struggle to survive in the first years of operation. Indeed, Soriano and Montoro-Sanchez (2011) suggest that decision making in conditions of uncertainty are a root metaphor of entrepreneurship. Yet to start up is to confront these hurdles of uncertainty (Açıkgöz et al. 2016), so new entrepreneurs need to be confident about how well they can cope (Dawson and Henley 2013; Storey 2011). This study takes inspiration from Baron (2008) and views confidence as the result of positive affect-new entrepreneurs tend to perceive ideas, situations and persons more favorably than others. This positive affect is found to directly influence cognitions by acting as a heuristic cue, simplifying perceptions and judgement in new entrepreneurs, in turn leading to often non-rational confidence and biased decision-making (Busenitz and Barney 1997). O'Leary (2011) describes this as judgement bias and a tendency to use intuition, especially when they lack experience (Soriano and Castrogiovanni 2012). Indeed, Montoro-Sánchez et al. (2009) suggest that such intuition may be more important than resources in how decisions are informed. Nonetheless, Tjosvold et al. (2013) suggest that creating solutions in response to emerging conditions remains a key challenge for all decision-makers.

The interplay of interpretation and action is influenced by how entrepreneurs make sense of their environment (Gheondea-Eladi 2016), and in particular, the risks associated with it (Weick et al. 2005). As Vittikh explains, "each actor has his own point of view on the world and on the processes therein" (2015, p. 72). Action choices are not neutral, but commensurate with the perspectives and frames held by the actors making the decisions (Giordano et al. 2017). Accordingly, entrepreneurs will differ in how they make sense of the business environment. Moreover, cognition is important (Kolfschoten and Reinig 2013) because cognitions affect decision expectations (Kolfschoten and Brazier 2013). To understand and explain entrepreneurial behaviour, one must take account of the different ways in which motivation (Torres and Sidorova 2015), strategic priorities (Tsironis and Matthopoulos 2015) and the use of knowledge (Liao and Barnes 2015), are influenced by the cognitive behaviours and sensemaking mechanisms of the entrepreneur. Specifically, we suggest that because they are new, and lacking the order of cognition which comes with regularisation of activity and experiential familiarity (Chia 2000; Hayward et al. 2006; Tsoukas and Chia 2002), the confidence which informs, or even taints, the new entrepreneur's decision-making may not be justified or even appropriate (Cassar 2010). Notwithstanding, confidence may help firms to see beyond initial start-up difficulties. A paradox exists between the need to be sufficiently confident to start up and the possibility of being inappropriately overconfident in relation to more established counterparts. This, then, presents the research problem; are new entrepreneurs more confident than their established counterparts and how does this impact their decisions and actions?

Though strong evidence suggests overconfidence is a liability bias from misreading signals (Van den Steen 2004), Stuart (2017) explains how potential value creation 
depends upon external uncertainties, and players have different beliefs about these uncertainties. Likely then is that new entrepreneurs are most at risk of failure, but perhaps naïvely underestimate these risks. However positive affect may also benefit entrepreneurial activity (Ucbasaran et al. 2010). Indeed, it has been argued that the enactment of confidence, as a cognition process (Drakopoulou Dodd and Anderson 2007), is essential for entrepreneurship and for the presentation of self as a new business founder (Anderson 2005). Confidence encourages a spirit in the individual entrepreneur (Cuervo et al. 2007), enhancing continual innovation as well as new firm formation. Ribeiro-Soriano and Urbano (2009, p. 420) suggest that "entrepreneurship and innovation research have an important common historical background". Indeed, Soriano and Huarng (2013) argue they can be viewed as different sides of the same coin. Perhaps this confidence, even naivety, in nascent entrepreneurship is a prerequisite in the innovation process. This study contributes to an understanding of confidence in entrepreneurship in two ways. First, it moves beyond confidence as a liability of newness and looks at how it impacts on decision-making, particularly in relation to risk and uncertainty. Second, it extends existing views on the role of confidence by looking to how the confidence of new entrepreneurs compares with those more established.

In order to illustrate our conceptual arguments, the perceptions of over 6000 new and more established small business owners in the UK are considered. A survey was conducted during the latest period of economic recession when insecurity loomed large, which provided us with the considerable research advantage of highlighting problems of risk and uncertainty (Anderson et al. 2010). This was followed up with recent telephone interviews from key informants in the sample. Unlike many studies of hypothetical confidence and cognitive biases, this empirically descriptive study sees confidence as related with actions, explaining confidence as manifest in the decision-making of the entrepreneur. Findings show that newer entrepreneurs are more confident, and probably over confident, in entrepreneurial decision-making relative to their longer established counterparts, allowing them to more optimistically move into the future.

\section{Confidence and Perception in Small Businesses}

A variety of studies investigate failure among young firms compared to higher survival rates in more established counterparts (Audretsch and Mahmood 1995; Cressy 1996; Mas-Verdú et al. 2015). A general explanation is presented as the liabilities of smallness (Anderson and Ullah 2014) and newness (Kale and Arditi 1998). Critical factors include: understanding availability in funding (Carter and Van Auken 2006); acquiring necessary skills (Pyysiainen et al. 2006); the knowledge that comes with time (Castrogiovanni et al. 2016) and ability to deal with uncertain environments (Anderson and Atkins 2001). Wang et al. (2015) also see trust asymmetries in small entrepreneurial firms in relation to larger enterprises, prompting many small firms to engage in an isolated form of strategic decision-making, limiting their collaborative relationships (Ribeiro-Soriano and Urbano 2009). Zhang et al. (2006) draw attention to how small firms may limit the scope of their environmental interaction and learning, but like Shepherd et al. (2015) see heterogeneity in how individual entrepreneurs approach this. For 
instance, they claim more innovative entrepreneurs may widen the scope to encourage learning and interpretation from others, while those seeking stability will look to contain knowledge and decision-making within one, or a few, controlling individuals. Thus, instead of considering resource limitations and access to capital, newness in entrepreneurship may be better explained by looking to the attitudes and decisionmaking of the controlling entrepreneur, often informed by personal aspirations and ideas of identity (Blackburn et al. 2013; Hoang and Gimeno 2010). Although there is extensive research into institutional and resource-based factors affecting new business (Chorev and Anderson 2006; Esteve-Perez and Manez-Castillejo 2008), fewer studies concentrate on entrepreneurs' perceptions as contributing to their firms' success, particularly in terms of managing in times of uncertainty (Cressy 2006).

Established research suggests that entrepreneurs, in addition to being more risktolerant (Kihlstrom and Laffont 1979), in times of complexity and uncertainty react with less strategically planned approaches (Sarasvathy 2007; Westerberg et al. 1997). They are adaptable and act in flexible ways (Zimmermann 1995), based on instinct rather than planned calculation. Welsh et al. (2017) argue that experience plays a role in performance here, tempering early stage optimism, and introducing more realistic expectations to the decision-making process. For example, Morris and Zahra (2000) found that new entrepreneurs' unfamiliarity with their own, and their firms', roles led to early mistakes in expectations. Similarly, Thornhill and Amit (2003) found that deficient managerial abilities and poor financial knowledge contributed to small businesses failure, a notion also pointed out as important by Carter and Van Auken (2006). It seems that newer entrepreneurs may have poor systems and strategies in place to make appropriate strategic decisions, making them more at risk of failing than older firms (Headd 2003). This study investigates if such liabilities can be attributed to overconfident attitudes in decision-making.

In this regard, confidence as an attitude manifest in strategic decision-making can impact on the firm in two ways. First, it may alter the entrepreneur's perception of risk in the environment, meaning more optimistically speculative decisions are taken. Second, high levels of belief in their own abilities may lead entrepreneurs to more reactive decision-making, favouring flexibility over constancy. This study now unpacks these two effects and develops research questions for exploration in this work.

\subsection{Perceptions of Risks}

Risk is a function of two factors; uncertainty and the significance of consequences (Kapoutsi et al. 2013). Brinckmann et al. (2010) propose that rather than 'muddling through' (Lindblom 1959) in the face of uncertainty and turbulence, entrepreneurs face the challenge and 'storm the castle'. Nonetheless, Cressy (2006) argues that entrepreneurs with such low risk aversion are more exposed to failure due to their inability to match growth rate with growth capacity. Certainly, attitudes toward risk play an important role in entrepreneurs' responses to choices and the amount of unknown variables (Kihlstrom and Laffont 1979), an issue heightened in a recessionary economic context (Nabi and Liñán 2013). But, to understand these behaviours, attention must be paid to their subjectively cognitive nature. For example, the notion of 
entrepreneurial self-efficacy (Bandura 1982, 1997; Schjoedt and Craig 2017) characterises entrepreneurs' belief in successfully accomplishing their tasks, not only informing their initial decision to start-up an enterprise (Prabhu et al. 2012), but also their proactivity in relation to decision-making more broadly. They need to maintain their optimism in order to continually move forward with the business (Adomako et al. 2016).

Brundin and Gustafsson (2013) imply that entrepreneurs lacking confidence are more likely to evaluate opportunities through associated risks, in contrast to their counterparts with higher levels of self-efficacy, who see commitment to risky venturing as opportunity. Although risk tolerance is integral to entrepreneurial decisions (Iyigun and Owen 1998), Wu and Knott (2006) highlight the importance of distinguishing between perceptions of market risk and ability, suggesting that where there is perceived uncertainty in the market environment, this may lead to risk averse behaviours. Specifically, the concept of distance informs decision-makers on the levels of risk associated with a particular environment, where situations and environments less familiar to the decision-maker pose a more risky and less preferred offering (Kraus et al. 2015). Perception therefore plays an important role in assessing the continued risks of the market environment (Ellsberg 1961), since perceptions serve as conciliators between behaviours and preferences when entrepreneurs face uncertainty (Tversky and Kahneman 1992). Koellinger et al. (2007) emphasise the connection between entrepreneurial perceptions and actions, which they see as potentially distorted by entrepreneurs' overconfidence.

According to Forbes (2005), overconfidence is a tendency to overestimate initial evaluations. Rather more poignantly, Lichtenstein and Fischoff (1977) described it as the extent of not knowing what they don't know - or as Donald Rumsfeld (formerly US Department of Defense) may put it, entrepreneurs are overconfident when there are many unknown unknowns. Thus the literature makes a strong case for the role of confidence, or overconfidence, in shaping how small firms react to risk. This study explores the extent to which this overconfidence recedes as the entrepreneur gathers experience and becomes more acutely aware of risk in the environment, and less uncertain of consequences. The question is raised:

Does entrepreneurial decision-making in relation to risk change the more experienced the entrepreneur becomes?

\subsection{Belief in Individual Ability}

Galanakis and Giourka (2017) suggest that small firms' adaptability in growth emanates from the entrepreneur's personal flexibility (Liao and Barnes 2015), based on being close to customers, information flow, their hands-on management approaches, and quick decision-making. Irvine and Anderson (2004) refer to this flexible capability as agility, and see it as particularly beneficial in survival contexts. Thus behavioural flexibility may be a response to uncertainty, a way of dealing with the ebb and flow of the environment. Boccardelli and Magnusson (2006) suggest this flexibility can itself become a dynamic capability in new firms, driven by an entrepreneurial logic to adapt their resources and offerings to changing market needs (Newey and Zahra 
2009). Cuervo et al. (2007) infer these contribute to the 'entrepreneurial spirit' so necessary for enterprise. However, there is strong evidence to suggest a tendency for entrepreneurs to overestimate their individual skills, abilities, and decision-making capacity to harness such capability.

This over-estimation again emanates from confidence (Camerer and Lovallo 1999; Koellinger et al. 2007; Moore and Kim 2003). Excessively positive, or naïve, perceptions of risk may be compounded by an unwarranted belief in individual ability to bring about a particular outcome. The presence of overconfidence in entrepreneurs, Baron (1998) argues, is a cognitive bias that is a necessary response to conditions of uncertainty. In support of this, research shows that overconfidence is higher in entrepreneurs than in non-entrepreneurial managers (Busenitz and Barney 1997), as people who are overconfident become naturally drawn to entrepreneurship, making them "less likely to imitate their peers and more likely to explore their environment" (Bernardo and Welch 2001, p. 302).

In addition to confidence, or overconfidence (Bayon et al. 2015), a belief in their own entrepreneurial ability may even compensate the entrepreneur for a natural aversion to risk and uncertainty (Salamouris 2013; Wu and Knott 2006), rendering her more able to accept the challenge and found a business. Alongside this clear impact on startup decisions, confidence in ability can also affect the way entrepreneurs approach other critical business factors, such as the use of knowledge (De Clercq and Arenius 2006), decisions on human capital and resources, processual awareness, and impacts of the environment (Kessler and Frank 2009). Moreover, in the general management literature, Bazerman and Neale (1982) believe that it affects how individuals negotiate difficult situations, while Hogarth and Makridakis (1981) similarly see effects in planning and forecasting and on managerial behaviour in operations (Willard et al. 1992). Simon and Houghton (2003) argue that the behavioural differences of overconfident managers was linked to the introduction and promotion of products and services with higher levels of risk and lower chances of success. Potentially a problem if the entrepreneur's perception and actual market conditions do not align (Guth et al. 1991). Critically, Koellinger et al. (2007) echo this when they note a negative correlation between the level of confidence and novice entrepreneurs' survival.

Thus, overconfidence may lead entrepreneurs to over-optimistically evaluate their skills and ability to deal with situations, and as a result fail to adopt sustainable practices. However, not all research characterises overconfidence negatively. Overconfident entrepreneurs tend to follow their own information, disregarding the 'herd' mentality, to become the independent spirits who demonstrate higher levels of innovation. Thus, optimistic views on their "sufficient skills, knowledge and ability" (Koellinger et al. 2007, p. 513) see entrepreneurs more likely to adopt an optimistic outlook in their projections and decisions, although with a high probability of overestimation on their chances of success. Such high levels of confidence in individual ability may be more apparent in the decision-making of newer entrepreneurs, in comparison to those who have perhaps learned the folly of the universal hero myth (Whelan and O'Gorman 2007). As such, this study questions:

Are newer entrepreneurs more optimistic in their decision-making with regards to ability in the firm? 
Confidence plays a major role in business processes, especially at start up. But it is also clear that overconfidence can be detrimental for business survival in that cognitive bias affects decisions by producing an overly optimistic view. Literature suggests that overconfidence is most likely in newer entrepreneurs, who may be less familiar with the consequences of risk and the limitations of their own ability. As new small firms represent business at its most vulnerable, it is crucial to examine how overconfidence may increase this vulnerability, which puts many firms at risk of failure.

Our research objective is to examine the extent to which confidence in new entrepreneurs is manifest in their managerial actions and decision-making. Unlike many other psychological studies of confidence (for example: Griffin and Tversky 1992; Zarnoth and Sniezek 1997) this study does not use a proxy measure of confidence set in an experimental situation. By assessing active entrepreneurs, the analysis can compare self-reported confidence of business owners with the outcomes of their decision-making processes, and also reflect on how this relates to self-reported business performance.

\section{Methodology}

The main data collection technique was a survey augmented by follow up interviews. The sample frame was some 60,000 members of the Federation of Small Businesses (FSB) in the UK. A total of 6289 small business owners completed the questionnaire, a $10.5 \%$ response rate. To establish statistical significance, where appropriate, Pearson Chi Squared calculation is used to test differences observed against expected frequencies in cases with two or more categories (Cramer 1994). With this analysis we intend only to illustrate the potential manifestation of confidence in entrepreneurial decision making. Thus, we do not offer causal relationships generalizable to the wider entrepreneurial population. Instead, we look to explore the heterogeneity of entrepreneurs in terms of how they assess and respond to their surrounding environment. To do this, we consider entrepreneurial decision-making at the time of a 'critical incident', i.e. the latest period of recession (Flanagan 1954; Holt and Macpherson 2010). By investigating the entrepreneurs during such a 'significant learning episode' (Sole and Edmondson 2002), we are able to understand entrepreneurial behaviour at a time of their own revision and reflection on their approach to the environment.

The questionnaire was kept short and simple to encourage participants to complete the survey. Respondents were also asked to respond to open-ended questions (Balnaves and Caputi 2001). This allowed colourful examples to illustrate particular trends or phenomena. Many excerpts are included from this qualitative data in the analysis to provide narrative authenticity to findings and offer some explanatory insight. Participants were asked if they were willing to be contacted for interview and 2300 participants agreed to follow up interviews. However, only a limited number of 'interested' respondents were interviewed at a later date to investigate longer term results. This was not entirely successful, due to difficulty in tracing many of the newer respondents. The study cannot confirm that they have gone out of business, but this or moving, seems the most likely reason. 
Table 1 Sample

\begin{tabular}{|c|c|c|c|c|c|}
\hline & $\%$ of total & $\begin{array}{l}\text { Operating }<1 \text { year } \\
(\%)\end{array}$ & $\begin{array}{l}\text { Operating } \\
1-3 \text { years }(\%)\end{array}$ & $\begin{array}{l}\text { Operating } \\
4-5 \text { years }(\%)\end{array}$ & $\begin{array}{l}\text { Operating } \\
5+\text { years }(\%)\end{array}$ \\
\hline $\begin{array}{l}\text { Time in } \\
\text { operation }\end{array}$ & & 5 & 19 & 12 & 64 \\
\hline \multicolumn{6}{|l|}{ Business form } \\
\hline Sole owners & 41 & 50 & 44 & 43 & 38 \\
\hline Partnership & 18 & 17 & 16 & 15 & 19 \\
\hline Ltd. Company & 39 & 30 & 38 & 40 & 40 \\
\hline Other & 3 & 3 & 2 & 2 & 3 \\
\hline Male & 72 & 60 & 64 & 69 & 75 \\
\hline Female & 28 & 40 & 36 & 31 & 25 \\
\hline \multicolumn{6}{|l|}{ Respondent age } \\
\hline$<25$ years & 0.4 & 2 & 1 & 0 & 0 \\
\hline 25-40 years & 18 & 30 & 31 & 25 & 12 \\
\hline $41-55$ years & 51 & 55 & 52 & 53 & 51 \\
\hline $56+$ years & 31 & 12 & 16 & 22 & 37 \\
\hline
\end{tabular}

Descriptive statistics combine with qualitative narrative (Gartner 2010) based on the participants' statements to arrive at the study's findings. Analysis of the responses is based on rounded percentages and represents the frequency of responses rather than the totals of survey respondents. In line with the study's research problem, data are categorised into four groups: new businesses, operating for less than 1 year; businesses in operation for 1-3 years; businesses in operation for 4-5 years; and those in operation for more than 5 years.

\subsection{Description of the Sample}

Most of the respondents had been in operation for more than 5 years (64\%), with novice businesses comprising 5\%. The largest group (41\%) of participants are sole proprietors. Among businesses operating for more than 5 years, the number of sole proprietors is lower than the newly established ones (38 vs. 50\%), suggesting a pathway from sole proprietor to a more structured firm. $72 \%$ of participants were male and $28 \%$ female. Over 11 defined business sectors are represented in the sample; from agricultural, fishing and forestry (covering $1 \%$ of total responses) to businesses in the retail sectors (covering the higher proportion of the sample at 17\%). A breakdown on the sample in relation to business age is shown in Table 1.

\section{Findings}

The study's research objective is to examine the attitudes of entrepreneurs to risk and decision-making, investigating if these attitudes change over time as initial confidence, 
or overconfidence, is tempered. To do this, how the entrepreneurs perceive their firm's performance in the risk-laden environment of a recession is considered from three time dimensions: reflective views on performance prior to the recessionary period; current performance in the midst of recession; and potential future business performance after economy recovery. In such a way, the entrepreneurs' attitudes to risk in the environment are reflected. Second, some of the actions taken by entrepreneurs in response to environmental cues are examined. In particular, the study considers decisions on pricing (Piercy et al. 2010) and operational changes, such as staffing (Lai et al. 2016), as areas in which small firms can be reactive, even tactical in times of uncertainty. With this second stage of our examination, we gauge the entrepreneurs' belief in the abilities of the firm, as a proxy for belief in their own ability.

\subsection{Perceptions of Business Performance}

Table 2 presents the self-reported data on how well small firms were performing before the recession; their current performance and current sales compared with up to 3 years previously. These data present a picture of the comparative perceptions on business performance of new and established firms. In total, $70 \%$ of all businesses had experienced growth within the previous 3 years and only $13 \%$ reported contracting. Of all the firm age groups, a greater proportion of older firms reported previous growth.

However, looking at current performance amongst new firms, a dichotomy is presented with $42 \%$ doing very well or well and $39 \%$ doing badly or very badly. Lower frequencies are noted where older firms report doing well (32\% of those 5 years and over) and the oldest group reports the poorest performance. For those experiencing little change, the highest percentage is in the established firms. These data seem to indicate more volatility amongst newer firms' perception of performance. Interestingly, when comparing those reporting doing badly and very badly, older firms seem more pessimistic in this regard. One longer established respondent summed this up:

$25 \%$ increase in sales over three years ago, but the current situation is already causing a drop in sales.

Overall, $42 \%$ of novice businesses reported that they are performing well or very well, compared to an average of $35 \%$ of all businesses. Most telling are the reported sales. Of those who had experienced sales increases in the past 3 years, the midto-older age ranges reported more frequently than expected, compared to only $32 \%$ of newer firms. But more substantially, those reporting decreased sales comprised $52 \%$ of new firms and an average of $50.4 \%$ of the older firms. Perhaps this shows new businesses' optimism in evaluating their current performance, regardless of actual sales activity suggesting faltering performance. One of the newer respondents summed up this optimism nicely:

Being a new business is something of a blessing in the present economic climate as I do not have previous year's figures to compare, so I am not as down hearted as older firms. 


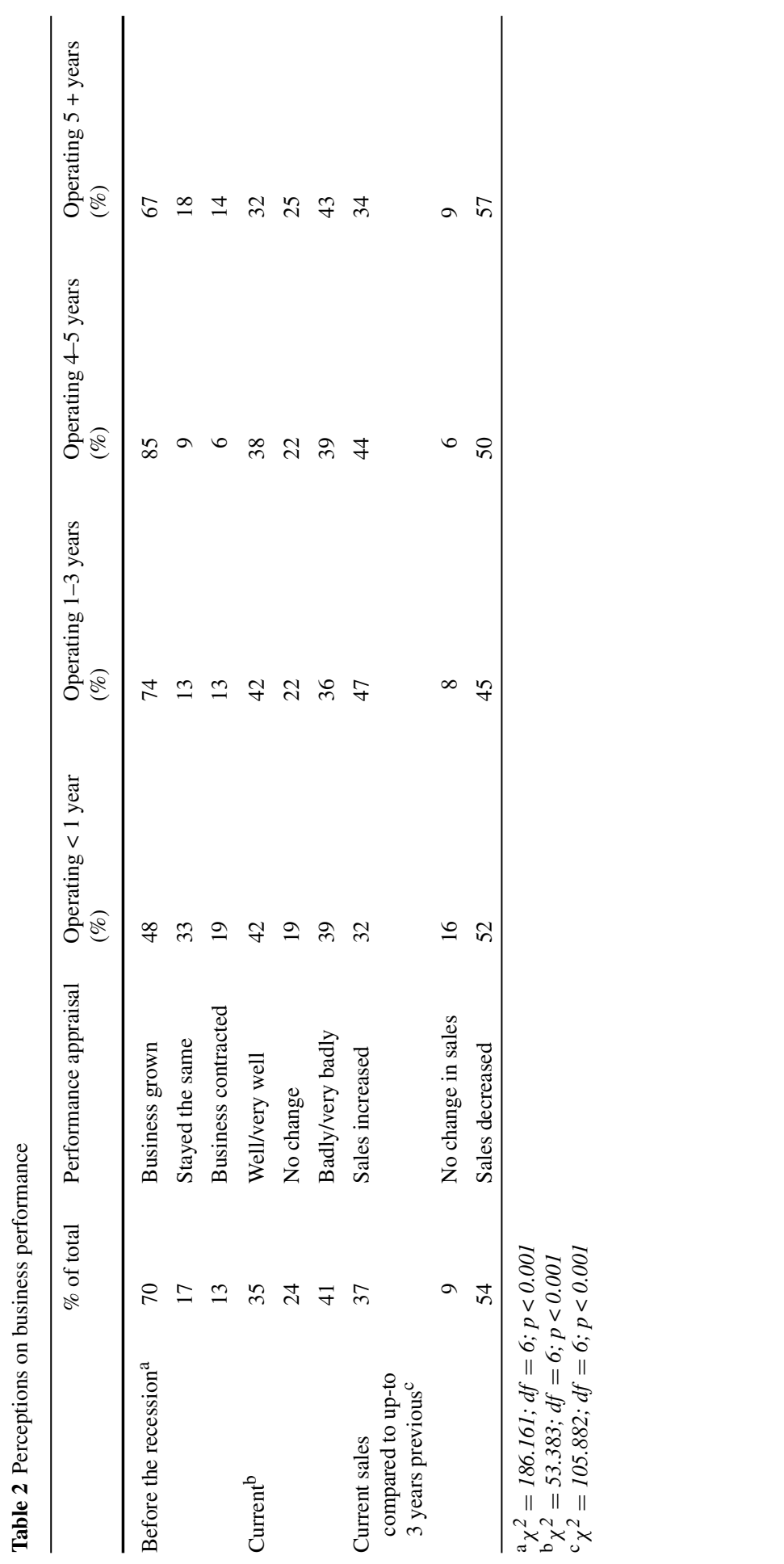


Looking to the future, respondents were more generally asked if they thought things would get better soon (Table 3); $42 \%$ of new businesses said they are optimistic that things will get better soon. But only $26 \%$ of established businesses thought that the situation would improve in the short term. Contrastingly $27 \%$ of established businesses anticipated worsening economic conditions compared to $13 \%$ of new businesses. Given the generally accepted greater likelihood of new businesses being more vulnerable to risks, the confidence of novice firms in these difficult times seems unduly optimistic.

\subsection{Actions Taken: Pricing}

Sales levels are an indicator of business health, in as much as falling sales presents a more precarious position and potential cash flow problems. But it is worth looking at the firms' pricing strategies because price reductions have an immediate impact on profitability. $47 \%$ of new and $38 \%$ of relatively new firms reduced their prices. This compares with some $35 \%$ of the older firms. It seems then that newer firms are buying sales to the detriment of profitability. Whilst this may be necessary to maintain cash flow, in the long run it is extremely dangerous.

Clients are forcing prices down for us and competitors, not sustainable and not sure how long we can maintain at this point

And,

Not so sure if I can sustain the current price structure as we are cutting our profit margin quite drastically

This compares to more established businesses, where there is greater awareness that, with profit squeezed, prices should be amended upwards. But this decision is tainted with worry of the consequences:

We should put up labour rates but are not confident to do so. Profit has been reduced

The levels of price reduction are also important. For instance, a price reduction of $10 \%$ would reduce net profit dramatically. As one well established respondent reported:

In some cases we have reduced prices as a temporary measure to help clients and secure orders against competitors. These competitors may not be in business much longer and are quoting silly prices as a desperate measure and last ditch effort to remain in business.

In combination with reduced sales volume, and unchanged or increased costs, deep price cuts may be unsustainable. But half of the newer respondents had taken this route and reduced prices by more than $10 \%$. This compares with older firms, of whom some $39 \%$ had this level of price cutting. Clearly, many newer small businesses have made themselves very vulnerable, demonstrated in Table 4.

Nonetheless new firms expressed both optimism and determination: 


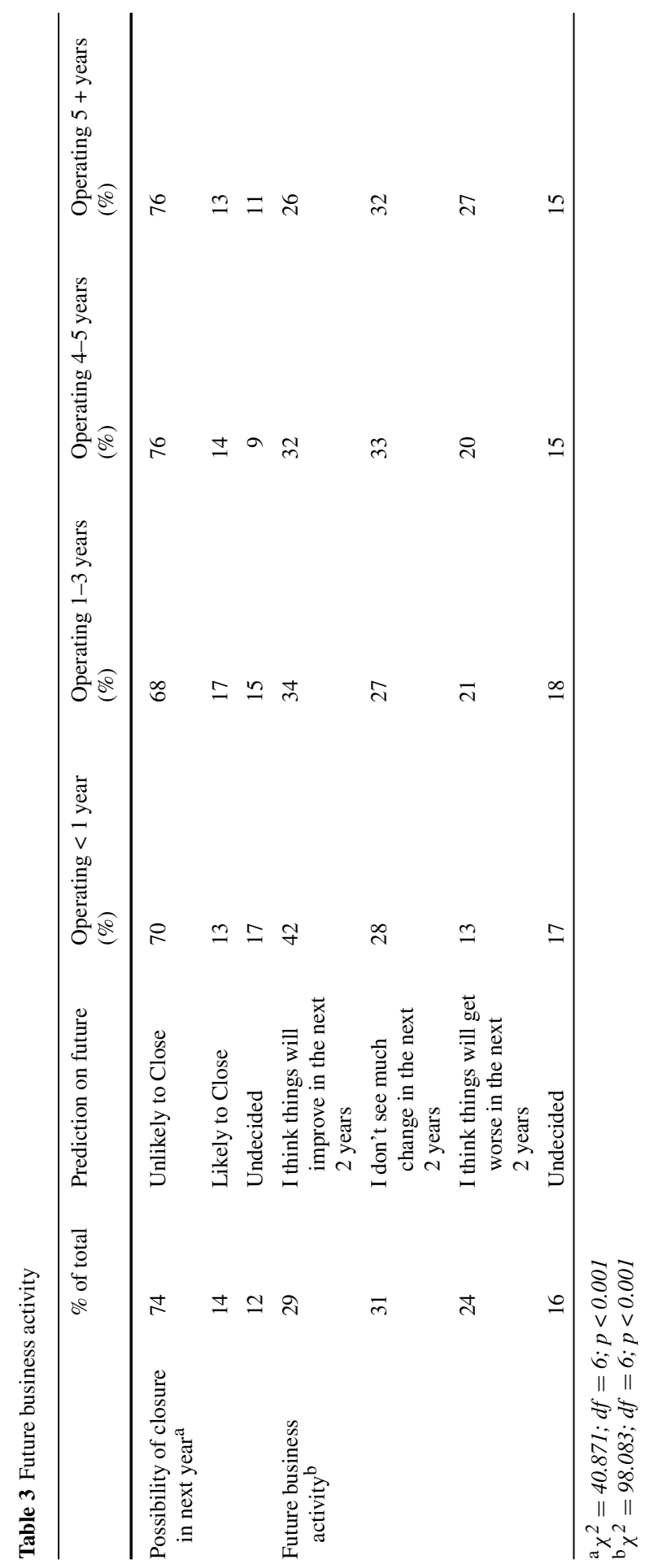




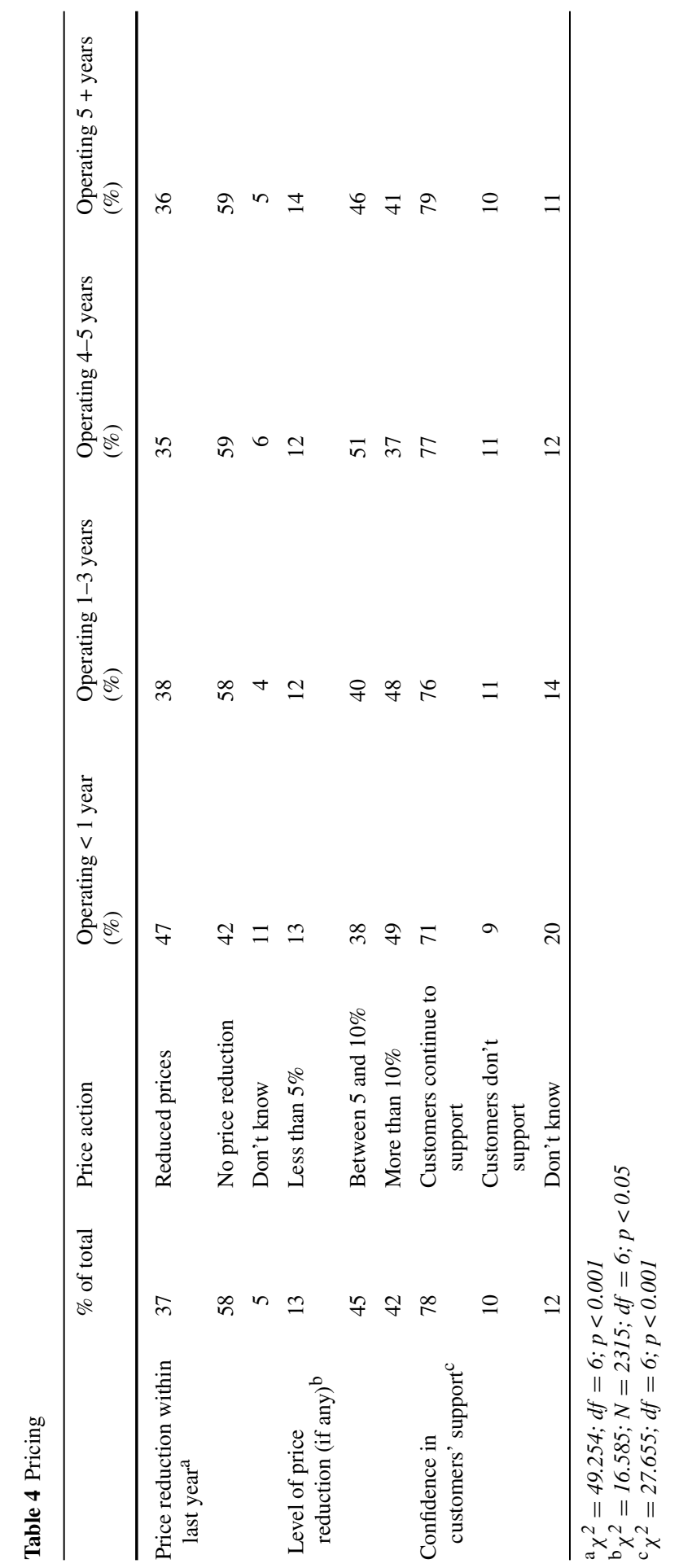


I feel our business is a success in the making and if I had to sell my own home to make this work (if I could sell it), I would do so.

Compared to the more calculated and pragmatic comments of established respondents:

We were improving sales and turnover but from now on I see a decline in sales and profits which is starting to take effect now.

With one which:

Diversified business (in order) to cope with changing consumer demands.

Respondents were also asked about customer loyalty and found that $78 \%$ of all businesses were confident about customer support. Of these, fewer of the new firms (71\%) than the established firms (79\%) were confident about customer loyalty. Moreover $20 \%$ of novice businesses did not know if their customers would continue to support them, versus $11-14 \%$ in more established businesses. This uncertainty may suggest that new businesses, lacking previous experience and a loyal customer base, are more exposed to the impacts of the recession.

\subsection{Actions Taken: Operational}

Operationally, first asked about any changes in the number of staff employed, or the number of hours staff worked, just under half of all respondents reported no change. Focusing on those who had reduced staff number or hours, only $19 \%$ of new businesses had made any reductions. In comparison, 32\% of firms 1-3 years old and 39\% of those older than 3 years, had made reductions. It appears that more of the older firms have responded by reducing staff costs than young firms. In part, this may be explained by the size of new firms better matching their environment because of their newness. On the other hand, it may indicate that older firms understood the implications of the recession and took action to address the problems (Table 5).

The majority of respondents (just over 50\%) reported making changes to the way their businesses operate. However, the smallest group was the new businesses, with only $41 \%$ saying that they made changes to their operations. Again this may indicate the extent of novice businesses owners' confidence. A range of coping tactics is found: asking for bigger deposits from customers; reduction and/or elimination of non-essentials costs; monitoring activities more closely and becoming more efficient; being more proactive in collecting debts; reducing wastage of resources and products; diversifying into other products and/or services, markets; introducing tighter credit control; reduction in overhead costs; reducing stock; more proactive in finding work/business. Some changes were dramatic:

We have gone from contractors to house building for ourselves

We were predominantly supplying the trade but now focus on e-commerce

Many businesses (46\%) tried to increase sales but more than two-thirds of new firms $(67 \%)$ favoured this strategy. In comparison, attention is drawn to how established firms are working to maintain sales 26 versus $15 \%$ of new firms. But the most noteworthy 


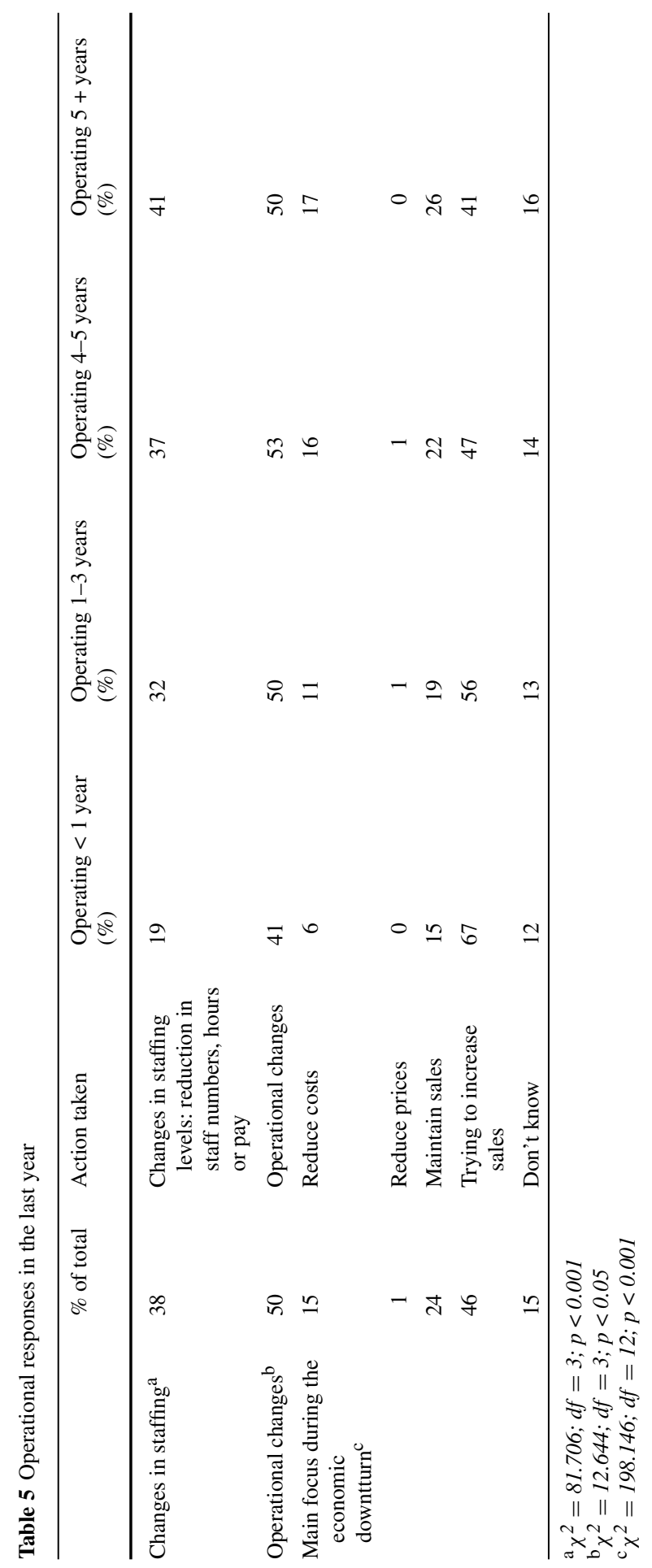


Table 6 Key findings

\begin{tabular}{ll}
\hline Perception of performance & Older enterprises more likely to report previous growth \\
& Older enterprises more pessimistic on current performance \\
& Both older and newer enterprises see likelihood of closure \\
& Newer enterprises more optimistic of future \\
Actions taken: pricing & Newer enterprises more willing to reduces prices \\
& Newer enterprises more likely to make larger price concession \\
& Older enterprises more confident of customer loyalty \\
Actions taken: operational & Older enterprises more likely to change staffing and operational structures \\
& Older enterprises more focused on maintaining performance/reducing costs \\
& Newer firms more focused on increasing sales \\
\hline
\end{tabular}

item was how $17 \%$ of the established firms are focusing on reducing costs compared to only $6 \%$ of new firms. For example;

In the finance business we have downsized our offices and moved premises to make sure that we are not wasting money.

The aim is to keep prices up and competitive while putting pressure on reducing raw material prices through resourcing and supplier negotiation.

In terms of actions in response to the recession, it seems that novice entrepreneurs are doing much less to reduce costs. Instead they are striving to increase sales but with lower margins. This suggests a high degree of confidence in their business approach which may not be justified. In light of the more prudent responses by those more experienced, it may even seem close to foolhardy. Certainly, around a quarter of all respondents thought they might have to close in the next 12 months. Of the new businesses, $70 \%$ were confident about not closing, yet $76 \%$ of the longer established entrepreneurs seen closure unlikely. A summary of the key findings related to the discussion is presented in Table 6:

\section{Discussion and Conclusions}

If luck favours the brave, then the unbound optimism of new entrepreneurs may be directly complicit in their creation of chance (Storey 2011). This is how society likes to see entrepreneurs in the early stages, 'storming the castle' regardless of the risks (Brinckmann et al. 2010), a hero in the face of certain failure (Whelan and O' Gorman 2007). Such myth and legend inform the mental constructs of individuals and provide a normalised behaviour of risk-taking, to which new entrepreneurs, bereft of their own experience, model behaviour and gauge legitimacy (Lounsbury and Glynn 2001). However, this study set out to consider if this confidence in the face of risk changes over time, as the fresh-faced maverick becomes a battle weary survivor. The investigation looks to what this may mean for perceptions to risk, and ultimately, decision-making in the business. 
By considering perceptions of risk, it seems that greater calculation takes place in the mind of more experienced entrepreneurs. This certainly suggests that, as entrepreneurs develop and gain experience from environmental volatility, and even the demise of peers, they hold a more realistic view of the market and make decisions more aligned to market demands. Such a finding would support Toft-Kehler et al. (2014) by demonstrating the application of learning as the entrepreneur becomes more practiced in their environment, rendering them able to translate their experience into more cautious expertise (Castrogiovanni et al. 2016; Welsh et al. 2017). In contrast, new entrepreneurs seem more determined to consider themselves performing well in their current situation, apparently impervious to evidence to the contrary, in the form of sales. At first sight, this may seem naïve on the part of new entrepreneurs, a characteristic which Goel and Karri (2006) may consider as over-trust in the nurturing potential of the environment. However, instead of consigning new entrepreneurs to the fate of unknown vulnerability (Cressy 2006), one should also consider how risk-aversion, developed through experience, may lead to a creeping conservatism in established entrepreneurs, perhaps artificially holding the firm back from innovation and growth (Herranz et al. 2015). The boldness of new entrepreneurs, supported by this study's findings, can be seen as a necessary trait to push the business forward, conceptually linking entrepreneurial confidence to more innovative and forward-looking perspectives of the environment (Ribeiro-Soriano and Urbano 2009; Soriano and Huarng 2013).

While Hmieleski and Baron (2009) suggest that entrepreneurs of every ilk view both their past and future through rose-tinted lenses, this study finds that more experienced firms emphasise 'better days' in the past more than new entrepreneurs. Dips in trade, though explained by recessionary environmental circumstances, are considered poor performance in comparison to previous activity. Notably, this seems to carry into pessimism in future dimensions. Newer entrepreneurs are considerably more optimistic on improvements in performance in the near future. There is a clear confidence here, in the face of troublesome sales reductions and despite all the liability and vulnerability of newness, new entrepreneurs maintain a more optimistic outlook over more experienced counterparts. In can be suggested that this optimism is afforded to new entrepreneurs as they do not have the weight of previous performance comparisons on their shoulder, and are not directly equating sales to doing well. Perhaps new entrepreneurs are not burdened by historical comparisons, which serve only to depress mind-sets at the time of downturn, no harking back to how good it was before the recession hit. In such a way, the folly of youth, may be keeping new entrepreneurs out of the doldrums.

Without an acute knowledge of environmental risk or the burden of past glory days, new entrepreneurs must gauge their plans and forecasts against belief in their own ability to create value in uncertainty (Stuart 2017). Simon and Houghton (2003) found this belief to often translate into confidence in products and services offered, regardless of evidence to the contrary. This study finds evidence to support this added confidence in new entrepreneurs; while they are willing to reduce price, and sacrifice margin to considerable extent in order to bolster sales, they are less likely to make operational changes in how they go about their business. In comparison, more established entrepreneurs seem more willing to consider changing the structure and focus on the 
business to deal with environmental changes and reduce costs. Koellinger et al. (2007) suggest that such certainty in set-up and offering, evident in the newer entrepreneurs, emanates from satisfied self-reflection on their own skills and ability.

While reductions in price show some element of flexibility as a dynamic capability in the context of a new entrepreneur, allowing them to ebb and flow with the environment as Newey and Zahra (2009) suggest, the extent to which new entrepreneurs are willing to reduce price may lead to vulnerability in the long-term (Cressy 2006). This rather short-sighted reactionary view on how to respond to environmental downturns may uncover limitations in the management ability of new entrepreneurs, where novelty to the situation makes them less willing to move away from their original plan, their original set-up, and their initial strategies of organisational purpose (Shepherd et al. 2000). Clearly, narrow organisational skills play a role here, however, this may also be explained by the persistence of an entrepreneurial hero complex in new entrepreneurs (Nijkamp 2003). The findings here suggest newer entrepreneurs are more tied to their initial conception on the configuration of resources. Instead of being willing to take their cues from the environment and restructure their operational set-up, new entrepreneurs seem to hold strong faith, or confidence, in what they do and how they do it, and only look to meddle with market-facing factors such as prices and sales.

\subsection{Implications and Future Research}

This study set out to explore how entrepreneurial sensemaking is influenced by variations in confidence between new and more established entrepreneurs. Bringing together attitudes and actions, the study suggests that new entrepreneurs are more confident about their abilities and more optimistic than experienced owners. In the light of their actions in the face of the recession, the extent of this confidence can seem inappropriate, even ill-judged. In comparison to more conservatively-minded counterparts, they seem overconfident. But one should not forget that starting a business requires a high degree of confidence, often powered by a belief in idiosyncratic ability and environmental perception (Eckhardt and Shane 2003). The range of responsibilities, risks and rewards demand a positive reflection on skill and self-efficacy. A completely rational approach, untampered by optimism and confidence, may not lead to start-up at all, and would certainly not lead to the form of open innovation so sought after in today's society (Scozzi et al. 2017). It is worth considering who demonstrates the most 'entrepreneurial spirit' (Cuervo et al. 2007) of the two, the older or younger entrepreneurs. New entrepreneurs seem to place emphasis on hope rather than prudence, and an optimism which permeates their future orientation.

The study's key theoretical contributions are achieved in the way confidence is connected to tangible decision-making. Thus furthering the concept of confidence from the abstract, to an influence manifest in actual business practice. In this way, the findings are able to consider the effects of confidence, not only at business start-up, but in day-to-day operations. As the study was set in the context of a burgeoning recession, impacting sales and intensifying competition, these issues are accentuated and the consequences of actions amplified. Also, the study contributes to an understanding of how entrepreneurial attitudes change with experience. The primary focus of 
new entrepreneurs on increasing sales through dramatic price reductions, rather than reducing costs, suggests greater confidence in their set-up and operational configurations than more established firms. Older entrepreneurs took a more defensive stance, consolidating and retrenching to adapt to the downturn. Thus, the study challenges notions of universal entrepreneurial character by gaining insight on the evolution from idealist novice, to battle-weary business owner. Each of these entrepreneurial characters makes sense of themselves and their environment in different ways, with their entrepreneurial behaviour impacted as a result.

A number of practical and policy-related implications can be taken from this study's findings. Although we were not primarily interested in innovation here, decisions about innovation also deal with uncertainty and the confidence to act within a risk context. Consequently, we argue that our findings may be useful in understanding innovation decisions not only in entrepreneurs, but in other aspects of organisational life where there is a mix of new and more experienced decision-makers. Principally, the way new entrepreneurs perceive risk and make brazenly confident decisions to survive could be inadvertently making them more vulnerable to failure, and so perceptions of risk are highlighted as an important area for consideration in entrepreneurship education and business support. However, in light of the conservatism presented by older entrepreneurs, tempered confidence may indeed limit small business growth and innovative practices, implicating the role of policy-makers to ensure experienced entrepreneurs maintain enough optimism to move forward.

As with all descriptively empirical studies of this nature, there are a number of limitations to consider. Primarily, attempts to extend the study by talking to novices after they had acquired experience were not successful. A retrospective view would be very useful in this regard, where a future study may look to chart the development of confidence over time, and the subsequent impact on decision-making. Furthermore, while a particular strength of this study is in its mixed-method approach, it is necessary to consider the more casual relationships behind these decisions and actions. One potentially fruitful avenue to follow is in the application of fsQCA to examine the complex relationships between context, entrepreneurial perception, and innovation in decision-making (Kraus et al. 2017). In this study, we have uncovered illustrative evidence of our conceptual arguments around the role of confidence and the heterogeneity of entrepreneurial perception and sensemaking. There is much scope to broaden our understanding by acknowledging that individual entrepreneurs will have many varied perspectives on increasingly complex environmental issues.

Acknowledgements The authors express great thanks to the special issue guest editors and two annonymous reviewers for their very construcive comments of previous versions of this work.

Open Access This article is distributed under the terms of the Creative Commons Attribution 4.0 International License (http://creativecommons.org/licenses/by/4.0/), which permits unrestricted use, distribution, and reproduction in any medium, provided you give appropriate credit to the original author(s) and the source, provide a link to the Creative Commons license, and indicate if changes were made. 


\section{References}

Açıkgöz A, Günsel A, Kuzey C, Zaim H (2016) Team foresight in new product development projects. Group Decis Negot 25(2):289-323

Adomako S, Danso A, Uddin M, Ofori-Damoah J (2016) Entrepreneurs' optimism, cognitive style and persistence. Int J Entrep Behav Res 22(1):84-108

Anderson AR (2005) Enacted metaphor: the theatricality of the entrepreneurial process. Int Small Bus J 23(6):587-603

Anderson AR, Atkins M (2001) Business strategies for entrepreneurial small firms. Strateg Chang 10(6):311-324

Anderson AR, Ullah F (2014) The condition of smallness: how what it means to be small deters firms from getting bigger. Manag Decis 52(2):326-349

Anderson AR, Osseichuk E, Illingworth L (2010) Rural small businesses in turbulent times; impacts of the economic downturn. Int J Entrep Innov 11(1):45-56

Audretsch DB, Mahmood T (1995) New firm survival: new results using a hazard function. Rev Econ Stat 77:97-103

Balnaves M, Caputi P (2001) Introduction to quantitative research methods: an investigative approach. Sage, London

Bandura A (1982) Self-efficacy mechanism in human agency. Am Psychol 37(2):122-147

Bandura A (1997) Self-efficacy: the exercise of control. W. H. Freeman, New York

Baron R (1998) Cognitive mechanisms in entrepreneurship; why and when entrepreneurs thing differently from other people. J Bus Ventur 13(4):275-294

Baron RA (2008) The role of affect in the entrepreneurial process. Acad Manag Rev 33(2):328-340

Bayon MC, Vaillant Y, Lafuente E (2015) Initiating nascent entrepreneurial activities: the relative role of perceived and actual entrepreneurial ability. Int J Entrep Behav Res 21(1):27-49

Bazerman M, Neale M (1982) Improving negotiation effectiveness under final offer arbitration. J Appl Psychol 67(5):543-548

Bernardo AE, Welch I (2001) On the evolution of overconfidence and entrepreneurs. J Econ Manag Strategy 10(3):301-330

Blackburn RA, Hart M, Wainwright T (2013) Small business performance: business, strategy and ownermanager characteristics. J Small Bus Enterp Dev 20(1):8-27

Boccardelli P, Magnusson MG (2006) Dynamic capabilities in early-phase entrepreneurship. Knowl Process Manag 13(3):162-174

Brinckmann J, Grichnik D, Kapsa D (2010) Should entrepreneurs plan or just storm the castle? a metaanalysis on contextual factors impacting the business planning-performance relationship in small firms. J Bus Ventur 25(1):24-40

Brundin E, Gustafsson V (2013) Entrepreneurs' decision making under different levels of uncertainty: the role of emotions. Int J Entrep Behav Res 19(6):568-591

Busenitz L, Barney J (1997) Differences between entrepreneurs and managers in large organizations: biases and heuristics in strategic decision making. J Bus Ventur 12(1):9-30

Camerer CF, Lovallo D (1999) Overconfidence and excess entry: an experimental approach. Am Econ Rev 89(1):306-318

Carter R, Van Auken H (2006) Small firm bankruptcy. J Small Bus Manag 44(4):493-512

Cassar G (2010) Are individuals entering self-employment overly optimistic? an empirical test of plans and projections on nascent entrepreneur expectations. Strateg Manag J 31(8):822-840

Castrogiovanni G, Ribeiro-Soriano D, Mas-Tur A, Roig-Tierno N (2016) Where to acquire knowledge: adapting knowledge management to financial institutions. J Bus Res 69(5):1812-1816

Chia R (2000) Discourse analysis organizational analysis. Organization 7(3):513-518

Chorev S, Anderson AR (2006) Marketing in high-tech start-ups: overcoming the liability of newness in Israel. Int Entrep Manag J 2(2):281-297

Cramer D (1994) Introducing statistics for social research. Routledge, London

Cressy RC (1996) Are business startups debt-rationed? Econ J 106:1253-1270

Cressy RC (2006) Why do most firms die young? Small Bus Econ 26(2):103-116

Cuervo Á, Ribeiro D, Roig S (2007) Entrepreneurship: concepts, theory and perspective. Introduction. In: Cuervo Á, Ribeiro D, Roig S (eds) Entrepreneurship. Springer, Berlin, pp 1-20

Dawson C, Henley A (2013) Over-optimism and entry and exit from self-employment. Int Small Bus J 31(8):938-954 
De Clercq D, Arenius P (2006) The role of knowledge in business start-up activity. Int Small Bus J 24(4):339-358

Drakopoulou Dodd S, Anderson AR (2007) Mumpsimus and the mything of the individualistic entrepreneur. Int Small Bus J 25(4):341-360

Eckhardt JT, Shane SA (2003) Opportunities and entrepreneurship. J Manag 29(3):333-349

Ellsberg D (1961) Risk, ambiguity, and the Savage axioms. Q J Econ 75:643-669

Esteve-Pére S, Mañez-Castillejo JA (2008) The resource-based theory of the firm and firm survival. Small Bus Econ 30(3):231-249

Flanagan JC (1954) The critical incident technique. Psychol Bull 51(4):327-358

Forbes DP (2005) Are some entrepreneurs more overconfident than others? J Bus Ventur 20(5):623-640

Galanakis K, Giourka P (2017) Entrepreneurial path: decoupling the complexity of entrepreneurial process. Int J Entrep Behav Res 23(2):317-335

Gartner WB (2010) A new path to the waterfall: a narrative on a use of entrepreneurial narrative. Int Small Bus J 28(1):6-19

Gheondea-Eladi A (2016) The evolution of certainty in a small decision-making group by consensus. Group Decis Negot 25(1):127-155

Giordano R, Brugnach M, Pluchinotta I (2017) Ambiguity in problem framing as a barrier to collective actions: some hints from groundwater protection policy in the Apulia Region. Group Decis Negot 26(5):911-932

Goel S, Karri R (2006) Entrepreneurs, effectual logic, and over-trust. Entrep Theory Pract 30(4):477-493

Griffin D, Tversky A (1992) The weighing of evidence and the determinants of confidence. Cogn Psychol 24(3):411-435

Guth W, Kumaraswamy A, McErlean M (1991) Cognition, enactment and learning in the entrepreneurial process. In: Churchill N, Bygrave W (eds) Frontiers in entrepreneurship research. Boston College, Wellesley, pp 242-253

Hayward ML, Shepherd DA, Griffin D (2006) A hubris theory of entrepreneurship. Manag Sci 52(2):160-172

Headd B (2003) Redefining business success: distinguishing between closure and failure. Small Bus Econ 21(1):51-61

Herranz N, Krasa S, Villamil AP (2015) Entrepreneurs, risk aversion, and dynamic firms. J Polit Econ 123(5):1133-1176

Hmieleski KM, Baron RA (2009) Entrepreneurs' optimism and new venture performance: a social cognitive perspective. Acad Manag J 52(3):473-488

Hoang H, Gimeno J (2010) Becoming a founder: how founder role identity affects entrepreneurial transitions and persistence in founding. J Bus Ventur 25(1):41-53

Hogarth R, Makridakis S (1981) Forecasting and planning: an evaluation. Manag Sci 27(2):115-130

Holt R, Macpherson A (2010) Sensemaking, rhetoric and the socially competent entrepreneur. Int Small Bus J 28(1):20-42

Irvine W, Anderson AR (2004) Small tourist firms in rural areas: agility, vulnerability and survival in the face of crisis. Int J Entrep Behav Res 10(4):229-246

Iyigun M, Owen A (1998) Risk, entrepreneurship and human capital accumulation. Am Econ Rev $88(2): 454-457$

Kale S, Arditi D (1998) Business failures: liabilities of newness, adolescence and smallness. J Constr Eng Manag 124(6):458-464

Kapoutsi I, Volkema RJ, Nikolopoulos AG (2013) Initiating negotiations: the role of Machiavellianism, risk propensity, and bargaining power. Group Decis Negot 22(6):1081-1101

Kessler A, Frank H (2009) Nascent entrepreneurship in a longitudinal perspective the impact of person, environment, resources and the founding process on the decision to start business activities. Int Small Bus J 27(6):720-742

Kihlstrom RE, Laffont JJ (1979) A general equilibrium theory of firm formation based on risk aversion. J Polit Econ 87(4):719-748

Koellinger P, Minniti M, Schade C (2007) “I think I can, I think I can”: overconfidence and entrepreneurial behaviour. J Econ Psychol 28(4):502-527

Kolfschoten GL, Brazier FM (2013) Cognitive load in collaboration: convergence. Group Decis Negot 22(5):975-996

Kolfschoten GL, Reinig BA (2013) Introduction to the special issue: "cognitive perspectives on group decision and negotiation". Group Decis Negot 22(5):867-872 
Kraus S, Ambos TC, Eggers F, Cesinger B (2015) Distance and perceptions of risk in internationalization decisions. J Bus Res 68(7):1501-1505

Kraus S, Ribeiro-Soriano D, Schüssler M (2017) Fuzzy-set qualitative comparative analysis (fsQCA) in entrepreneurship and innovation research-the rise of a method. Int Entrep Manag J. https://oi.org/ 10.1007/s11365-017-0461-8

Lai Y, Saridakis G, Blackburn R, Johnstone S (2016) Are the HR responses of small firms different from large firms in times of recession? J Bus Ventur 31(1):113-131

Liao Y, Barnes J (2015) Knowledge acquisition and product innovation flexibility in SMEs. Bus Process Manag 21(6):1257-1278

Lichtenstein S, Fischoff B (1977) Do those who know more also know more about how much they know? Organ Behav Hum Decis 20(2):159-183

Lindblom CE (1959) The science of "muddling through". Public Adm Rev 19:79-88

Lounsbury M, Glynn MA (2001) Cultural entrepreneurship: stories, legitimacy, and the acquisition of resources. Strateg Manag J 22(6-7):545-564

Mas-Verdú F, Ribeiro-Soriano D, Roig-Tierno N (2015) Firm survival: the role of incubators and business characteristics. J Bus Res 68(4):793-796

Montoro-Sánchez Á, Ortiz-de-Urbina-Criado M, Romero-Martínez AM (2009) The decision to use alliances as corporate entrepreneurship: the role of resources and skills. Group Decis Negot 18(5):431-448

Moore DA, Kim TG (2003) Myopic social prediction and the solo comparison effect. J Pers Soc Psychol 85(6):1121-1135

Morris MH, Zahra SA (2000) Adaptation of the business concept over time: the case of historically disadvantaged south african owner/managers. J Small Bus Manag 38(1):92-100

Nabi G, Liñán F (2013) Considering business start-up in recession time: the role of risk perception and economic context in shaping the entrepreneurial intent. Int J Entrep Behav Res 19(6):633-655

Newey LR, Zahra SA (2009) The evolving firm: how dynamic and operating capabilities interact to enable entrepreneurship. Br J Manag 20(s1):81-100

Nijkamp P (2003) Entrepreneurship in a modern network economy. Reg Stud 37(4):395-405

O'Leary DE (2011) The emergence of individual knowledge in a group setting: mitigating cognitive fallacies. Group Decis Negot 20(1):3-18

Piercy NF, Cravens DW, Lane N (2010) Thinking strategically about pricing decisions. J Bus Strategy 31(5):38-48

Prabhu VP, McGuire SJ, Dorst EA, Kwong KK (2012) Proactive personality and entrepreneurial intent: is entrepreneurial self-efficacy a mediator or moderator? Int J Entrep Behav Res 18(5):559-586

Pyysiainen J, Anderson AR, McElwee G, Vesala K (2006) Developing the entrepreneurial skills of farmers: some myths explored. Int J Entrep Behav Res 12(1):21-39

Ribeiro-Soriano D, Urbano D (2009) Overview of collaborative entrepreneurship: an integrated approach between business decisions and negotiations. Group Decis Negot 18(5):419-430

Salamouris IS (2013) How overconfidence influences entrepreneurship. J Innov Entrep. https://doi.org/10. $1186 / 2192-5372-2-8$

Sarasvathy SD (2007) Effectuation: elements of entrepreneurial expertise. Edward Elgar Publishing Ltd., Cheltenham

Schjoedt L, Craig JB (2017) Development and validation of a unidimensional domain-specific entrepreneurial self-efficacy scale. Int J Entrep Behav Res 23(1):98-113

Scozzi B, Bellantuono N, Pontrandolfo P (2017) Managing open innovation in urban labs. Group Decis Negot 26(5):857-874

Shepherd DA, Douglas EJ, Shanley M (2000) New venture survival: ignorance, external shocks, and risk reduction strategies. J Bus Ventur 15(5-6):393-410

Shepherd DA, Williams TA, Patzelt H (2015) Thinking about entrepreneurial decision making: review and research agenda. J Manag 41(1):11-46

Simon M, Houghton S (2003) The relationship between overconfidence and the introduction of risky products: evidence from a field study. Acad Manag J 46(2):139-150

Sole D, Edmondson A (2002) Situated knowledge and learning in dispersed teams. Br J Manag 13(s2):17-34

Soriano DR, Castrogiovanni GJ (2012) The impact of education, experience and inner circle advisors on SME performance: insights from a study of public development centers. Small Bus Econ 38(3):333-349

Soriano DR, Huarng KH (2013) Innovation and entrepreneurship in knowledge industries. J Bus Res 66(10):1964-1969 
Soriano DR, Montoro-Sanchez MA (2011) Introduction: the challenges of defining and studying contemporary entrepreneurship. Can J Adm Sci 28(3):297-301

Storey DJ (2011) Optimism and chance: the elephants in the entrepreneurship room. Int Small Bus J 29(4):303-321

Stuart HW (2017) Contingent contracts and value creation. Group Decis Negot 26(4):815-827

Thornhill S, Amit R (2003) Learning about failure: bankruptcy, firm age, and the resource-based view. Organ Sci 14(5):497-509

Tjosvold D, Peng AC, Chen NY, Fang SS (2013) Individual decision-making in organizations: contribution of uncertainty and controversy in China. Group Decis Negot 22(4):801-821

Toft-Kehler R, Wennberg K, Kim PH (2014) Practice makes perfect: entrepreneurial-experience curves and venture performance. J Bus Ventur 29(4):453-470

Torres R, Sidorova A (2015) The effect of business process configurations on user motivation. Bus Process Manag J 21(3):541-563

Tsironis LK, Matthopoulos PP (2015) Towards the identification of important strategic priorities of the supply chain network: an empirical investigation. Bus Process Manag J 21(6):1279-1298

Tsoukas H, Chia R (2002) On organizational becoming: rethinking organizational change. Organ Sci 13(5):567-582

Tversky A, Kahneman D (1992) Advances in prospect theory: cumulative representation of uncertainty. J Risk Uncertain 5(4):297-323

Ucbasaran D, Westhead P, Wright M, Flores M (2010) The nature of entrepreneurial experience, business failure, and comparative optimism. J Bus Ventur 25(6):541-555

Van den Steen E (2004) Rational overoptimism (and other biases). Am Econ Rev 94(4):1141-1151

Vittikh VA (2015) Introduction to the theory of intersubjective management. Group Decis Negot 24(1):67-95

Wang H, Peverelli PJ, Bossink BA (2015) The development of asymmetric trust in cooperation between large firms and SMEs: insights from China. Group Decis Negot 24(5):925-947

Weick KE, Sutcliffe KM, Obstfeld D (2005) Organizing and the process of sensemaking. Organ Sci 16(4):409-421

Welsh DH, Kaciak E, Trimi S, Mainardes EW (2017) Women entrepreneurs and family firm heterogeneity: evidence from an emerging economy. Group Decis Negot. https://doi.org/10.1007/s10726-017-95448

Westerberg M, Singh J, Hackner E (1997) Does the CEO matter? an empirical study of small Swedish firms operating in turbulent environments. Scand J Manag 13(3):251-270

Whelan G, O'Gorman C (2007) The Schumpeterian and universal hero myth in stories of Irish entrepreneurs. Irish J Manag 28(2):79-107

Willard G, Krueger D, Feeser D (1992) In order to grow the founder must go: a comparison of performance between founder-managed and non-founder managed high-growth manufacturing firms. J Bus Ventur 7(3):181-194

Wu B, Knott AM (2006) Entrepreneurial risk and market entry. Manag Sci 52(9):1315-1330

Zarnoth P, Sniezek JA (1997) The social influence of confidence in group decision making. J Exp Soc Psychol 33(4):345-366

Zhang M, Macpherson A, Jones O (2006) Conceptualizing the learning process in SMEs: improving innovation through external orientation. Int Small Bus J 24(3):299-323

Zimmermann KF (1995) Flexibility in the face of demand fluctuations: employment, capacity utilization, and industry structure. Int J Ind Organ 13(2):179-193 